\title{
Bacterial production in marine sediments: will cell-specific measures agree with whole-system metabolism?
}

\author{
Robert D. Fallon, Steven Y. Newell and Charles S. Hopkinson \\ University of Georgia Marine Institute, Sapelo Island, Georgia 31327, USA
}

\begin{abstract}
Estimates for bacterial production in nearshore western Atlantic Ocean sediments were made using the frequency of dividing cell and thymidine uptake methods. The frequency of dividing cell (FDC) method resulted in estimates in the range of 5 to $50 \mathrm{~g} \mathrm{C} \mathrm{m}^{-2} \mathrm{~d}^{-1}$. The thymidine uptake (THY) method resulted in estimates of 1 to $.8 \mathrm{~g} \mathrm{C} \mathrm{m}^{-2} \mathrm{~d}^{-1}$. Metabolic measurements based on sediment oxygen uptake show that the FDC estimates are unreasonably high, while THY estimates, which have been corrected for DNA extraction and thymidine dilution, are reasonable with respect to oxygen uptake data. Problems associated with these 2 bacterial production methods when used in sediments are discussed.
\end{abstract}

\section{INTRODUCTION}

Bacteria are believed to be important as mediators of matter and energy transfers in sediments (Fenchel and Blackburn, 1979; Meyer-Reil and Faubel, 1980), but few data are available on the dynamics of these populations. In spite of increasing knowledge about numbers (Christian et al., 1978; Meyer-Reil et al., 1978; Jones et al., 1979; Moriaty, 1977; Aller and Yingst, 1980) and geochemical activity (Christian and Wiebe, 1978; Jørgensen, 1978; Sørensen et al., 1979; Novitsky and Kepkay, 1981), rates of production and turnover in sedimentary bacterial populations are poorly understood. Using selective inhibition by antibiotics, attempts have been made to measure the contribution of bacteria to sediment oxygen demand (Hargrave, 1969; Smith, 1974; Hartwig, 1978; Van Es, 1982). However, results have been equivocal, and as Yetka and Wiebe (1974) have pointed out, antibiotics will only be effective on rapidly growing populations.

In recent reports a variety of approaches for measuring bacterial production in planktonic environments have been suggested, including diffusion chambers (Sieburth et al., 1977), glucose uptake (Delattre et al., 1979), thymidine uptake (Fuhrman and Azam, 1980. 1982), frequency of dividing cells (Hagström et al., 1979), and adenine uptake (Karl et al., 1981 a, b). We desire an approach which measures solely bacterial production in sediments. Therefore, not all those suggested above are applicable, either because of required sample manipulations or because they may not be specific for bacteria. Two techniques which should measure solely bacterial production in sediments are frequency of dividing cells (FDC) (Hagström et al., 1979) and thymidine uptake (THY) (Fuhrman and Azam, 1982). Preliminary reports on the use of these techniques in sediments were made recently (Moriarty and Pollard, 1981; Newell and Fallon, 1982). Both reports suggest that bacteria in sediments can be very active and turn over rapidly. In contrast, most previous reports on bacterial activity in sediments (Gerlach, 1978; Meyer-Reil et al., 1978; Pamatmat et al., 1981; Sorokin, 1981) concerned sedimentary populations which are relatively inactive, although Chocair and Albright (1981) have reported sedimentary bacterial populations which were quite active with respect to populations in the overlying water. In an attempt to clarify further this issue, we have compared the FDC and THY techniques in the Atlantic Ocean sediments of coastal Georgia and, as a test of their utility in sediments, compared estimates of bacterial productivity from these 2 approaches to estimates for maximal productivity as estimated from total benthic metabolism derived from in situ measurements of sediment oxygen uptake. 


\section{MATERIALS AND METHODS}

Sediment was collected from 3 stations $(0.25,6$, and $15 \mathrm{~km}$ offshore) in a transect running ESE from Sapelo Island $\left(31^{\circ} 23^{\prime} \mathrm{N}, 81^{\circ} 17^{\prime} \mathrm{W}\right)$ in the Atlantic Ocean. Stations depths were $2.4,6.7$, and $15.8 \mathrm{~m}$ respectively. Salinities ranged from 28 to $35 \%$ S. Sediments were 90 to $98 \%$ sand with some silt and clay (Howard et al., 1972). Organic contents ranged from 0.3 to $2.0 \%$ (Pinet and Frey, 1977). Samples were collected from shipboard using a Reineck box corer or by SCUBA diver using $3.7 \mathrm{~cm}$ I.D. chromed, thin wall tubing. Subcores, $3.2 \mathrm{~cm}$ diameter, were removed from the box core. Marsh sediment was also sampled on 22 October 1981 by hand coring with a $3.2 \mathrm{~cm}$ PVC plastic tube from the low intertidal creek bank below the vegetation line in Dean Creek, Sapelo Island, Georgia, USA. Marsh sediments are primarily silt and clay with small amounts of sand. Salinity in the creek varies from brackish to salty, depending on recent storm events. For all locations subsamples were removed at appropriate depths from the core tubes with cut-off plastic syringes and placed in glass vials.

\section{Thymidine uptake (THY)}

Sediment samples, approximately $3 \mathrm{ml}$, were placed in scintillation vials and $0.5 \mathrm{ml}$ of bacteria-free seawater $(0.2 \mu \mathrm{m}$ filtered) was added. To kill controls, an additional $0.3 \mathrm{ml}$ of $37 \%$ formaldehyde was added. Each sample then received $0.05 \mathrm{ml}$ of aqueous solution containing $25 \mu \mathrm{Ci}$ of methyl- ${ }^{3} \mathrm{H}$-thymidine (ICN, $50 \mathrm{Ci}$ mmole ${ }^{-1}$ ). Vials were sealed with a screw cap with a Teflon-coated silicone liner (Pierce Chemical Co., Rockford, IL, USA) after mixing of the sediment. Vials containing samples from 10 and $20 \mathrm{~cm}$ depths at the nearshore stations and from all depths in the marsh sediments were evacuated and flushed with neon 3 times in order to remove oxygen from the vials. Samples were incubated for 1 to $4 \mathrm{~h}$ in the dark at ambient temperature: 19 to $20^{\circ} \mathrm{C}$, nearshore and marsh, October $1981 ; 10$ to $11^{\circ} \mathrm{C}$, nearshore, February 1981 . Incubations were terminated by addition of $2.4 \mathrm{~N}$ $\mathrm{NaOH}$ to bring the final concentration in the sample to approximately $0.6 \mathrm{~N}$ (Moriarty and Pollard, 1981). Samples were kept cold (ice or refrigeration, maximum $48 \mathrm{~h}$ ) until extraction. Macromolecules were solubilized by heating the samples at $100{ }^{\circ} \mathrm{C}$ for $4 \mathrm{~h}$. After shaking, samples were then returned to refrigeration. Samples were centrifuged momentarily at low speed to settle suspended material and then $0.3 \mathrm{ml}$ of the supernatant was removed to a test tube on ice. To the $0.3 \mathrm{ml}$ of supernatant, ice cold $2.4 \mathrm{~N} \mathrm{HCl}$ was added to neutralize the extract, followed by $8 \mu \mathrm{l}$ of a $5 \mathrm{mg} \mathrm{ml}^{-1}$ aqueous DNA solution and $40 \mu \mathrm{I}$ of a $5 \mathrm{mg} \mathrm{ml}^{-1}$ aque- ous thymidine solution. After mixing, a volume of ice cold $10 \%$ trichloroacetic acid (TCA) equal to the combined volumes of the solutions above was added with mixing and the solution was chilled on ice for $45 \mathrm{~min}$. The precipitate was then collected on a $25 \mathrm{~mm}$, Gelman GN-6 membrane filter $(0.45 \mu \mathrm{m}$ pore size) at a vacuum of $250 \mathrm{~mm} \mathrm{Hg}$. The test tube originally containing the mixture was washed once with $2 \mathrm{ml}$ of ice cold $5 \%$ TCA. The wash was filtered and then the filter washed again with an additional $3 \mathrm{ml}$ of ice cold $5 \%$ TCA. A few drops of distilled water were placed on the filter as the chimney was removed to insure clean separation of the edges. Filters were placed in scintillation vials and allowed to dry. Then $0.3 \mathrm{ml}$ of $1 \mathrm{~N} \mathrm{HCl}$ was added and filters were heated to $100^{\circ} \mathrm{C}$ for 20 to $30 \mathrm{~min}$ to digest the deoxyribonucleic acid (DNA). After cooling, $2.5 \mathrm{ml}$ of 1:1 ethyl acetate:ethylene glycol monomethylether solution was added to dissolve the filter and $12 \mathrm{ml}$ of Aquasol II (New England Nuclear) was added for scintillation counting. Counting efficiencies were estimated from standard additions of ${ }^{3} \mathrm{H}$-toluene and channel ratios count. Standard errors are generally less than $30 \%$ of the mean in duplicate samples.

Possible isotope dilution by sedimentary pools of thymidine was tested in surface sediments by the method of Moriarty and Pollard (1981) on the February (1982) cruise. Also, the relative efficiency of extraction of DNA was estimated by comparing the recovery of radioactivity in TCA precipitable material from prelabeled bacterial cells. Estuarine water, $500 \mathrm{ml}$, was enriched with $0.5 \mathrm{~g}$ glucose and $0.1 \mathrm{~g}$ yeast extract. The suspension was continuously bubbled with air. After overnight growth at 20 to $22^{\circ} \mathrm{C}$ (increased turbidity was visible), $400 \mu \mathrm{Ci}$ of methyl ${ }^{3} \mathrm{H}$-thymidine was added and the cells were allowed to grow for $24 \mathrm{~h}$. Cells were recovered by centrifugation and the cell pellet was washed 3 times with phosphate-buffered saline (PBS), $0.1 M$, pH 7.2. The pellet was frozen. To test extraction efficiency, a portion of the cells was resuspended in PBS and added to sediment or artificial seawater. After addition of labeled cells, samples were immediately extracted following procedures of Fuhrman and Azam (1980) (for aqueous suspensions) or those described above (for sediment samples). The recovery by the Fuhrman and Azam (1980) procedure was arbitrarily assigned a value of $100 \%$.

\section{Direct-counts}

All glass- and plasticware used in sample handling was acid-washed and rinsed with $0.2 \mu \mathrm{m}$ filtered (bacteria-free) distilled water. Sediment samples $\left(2 \mathrm{~cm}^{3}\right)$ were injected into scintillation vials and $15 \mathrm{ml}$ of a 
bacteria-free seawater solution of formaldehyde $(2 \%)$ was added, with shaking. Vials of preserved water and sediment samples were stored at $4{ }^{\circ} \mathrm{C}$ until processing for microscopy (in $2 \mathrm{wk}$ ).

Samples were treated for bacterial direct-counting by the acridine-orange method (Hobbie et al., 1977 ; Rublee et al., 1978) as described in detail by Robertson and Newell (1982) for sediment samples. Briefly, these methods involve the following series of steps: (1) homogenization (5 min, about 15,000 I.p.m.); (2) dilution (to achieve approximately 20 cells per field in the final preparation); (3) 60-s staining in acridineorange solution $(0.01 \%$ in bacteria-free $2 \%$ formaldehyde solution in seawater); (4) filtration through $0.2 \mu \mathrm{m}$ pore-size Nuclepore polycarbonate membrane filters; (5) counting of bacterial cells on the filter via epifluorescence microscopy (Zeiss; HB0 50 lamp, 2X BG12 excitation filter, FT 510 beam splitter, LP 510 barrier filter). Counts, cell-volume measurements, and calculation were as described by Newell and Christian (1981); total cells were counted in 15 fields per sample and dividing cells in 30 fields per sample. Concentrations of cells in sediments were corrected for inefficiency of removal of attached cells using the factor ( $\mathrm{X}$ 1.5) given by Newell and Fallon (1982).

Because of the uncertainty of applicability of the dividing-cells method to filamentous or chain-forming cells, cells in chains of 3 cells or longer than $13 \mu \mathrm{m}$ (arbitrarily chosen) were not included in total cell counts for the purpose of calculating frequency of dividing cells. The proportion which these cells formed of the total cell counts in sediment samples ranged from 0.5 to $4.4 \%$ (Newell and Fallon, 1982).

\section{Benthic community metabolism}

Benthic community metabolism measured by monitoring sediment oxygen uptake provides a good estimate of total benthic activity. In situ measurements of benthic oxygen uptake were made using 2 to 4 darkened, low profile acrylic hemispheres (diameter $60 \mathrm{~cm}$, volume $47 \mathrm{l}$ ). Observations were conducted during summer, fall and winter (1981-1982) at stations from 1.6 to $10 \mathrm{~km}$ offshore along the transect running from Sapelo Island. The hemispheres were filled with water from the immediate area of sampling and gently placed on the bottom by SCUBA diver to minimize sediment disturbance and assure that an $8-\mathrm{cm}$ vertical flange was fully inserted into sediments. After an initial 30-min quieting period, hemispheres were sealed from overlying water and changes in dissolved oxygen concentration were followed during 4 to $6 \mathrm{~h}$ incubations. All experiments were run during daylight, making no attempt to investigate tidal or diurnal metabolic rhythms. Oxygen was measured with polarographic electrodes (Orbisphere Labs, Geneva, Switzerland) equipped with stirrers capable of keeping water in the chambers well-mixed. Dark bottles were contemporaneously incubated in situ to provide a correction for water column respiration. The change in dissolved oxygen was linear over the incubation indicating no disturbance of the benthic community. Dissolved oxygen concentrations never fell below $60 \%$ of initial values or below $4 \mathrm{mg} \mathrm{l}^{-1}$. Benthic community metabolism was calculated from changes in concentration over time after correcting for planktonic contributions (Hopkinson and Wetzel, 1982). The carbon equivalent of sediment oxygen uptake was calculated assuming a respiratory equivalent (RQ) of 1.0 (Nixon et al., 1980). Because all nearshore sediment locations include a 3 to $15 \mathrm{~cm}$ oxidized zone in the surface sediments, escape of reduced metabolic products (e.g., $\mathrm{H}_{2} \mathrm{~S}$ or $\mathrm{CH}_{4}$ ) is believed insignificant and the use of an RQ of 1 justified.

\section{RESULTS}

Data showing the recovery efficiency for TCA precipitable macromolecules from sand and clay sediments are shown in Table 1. Relative to the recovery of

Table 1. Recovery of TCA precipitable radioactivity from sediment

\begin{tabular}{|c|c|c|c|}
\hline Recovery & \multicolumn{2}{|c|}{ Sediment type } & $\begin{array}{l}\text { DPM } \\
\text { added }\end{array}$ \\
\hline DPM recovered & 59,350 & 99,775 & 111,980 \\
\hline Recovery efficiency & $53 \%$ & $89 \%$ & $100 \%$ \\
\hline \multicolumn{4}{|c|}{$\begin{array}{l}\text { - Based on recovery from prelabeled cells using the pro- } \\
\text { tocol of Fuhrmann and Azam (1980) }\end{array}$} \\
\hline
\end{tabular}

radioactivity using the protocol of Fuhrman and Azam (1980) in the absence of sediment, $\mathrm{NaOH}$ extraction of sediments recovered about $89 \%$ of the TCA precipitable radioactivity from clay sediments and $53 \%$ from sand (Table 1). Fig. 1 allows an estimate of isotope dilution by the sediments based on the method of Moriarty and Pollard (1981). The $y$ intercept of $-8 \mathrm{n}$

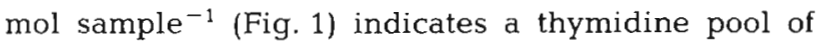
approximately $2.7 \mathrm{n} \mathrm{mol} \mathrm{ml}^{-1}$ sediment. Therefore the $0.5 \mathrm{n}$ mol of ${ }^{3} \mathrm{H}$-thymidine was diluted approximately 16 -fold and estimates of DNA synthesis must be corrected for such dilution.

Based on correction factors above and literature values for DNA content and cell size (Table 2), estimates for bacterial productivity in the sediments were calculated from the THY and FDC data. Fig. 2A (FDC) and 


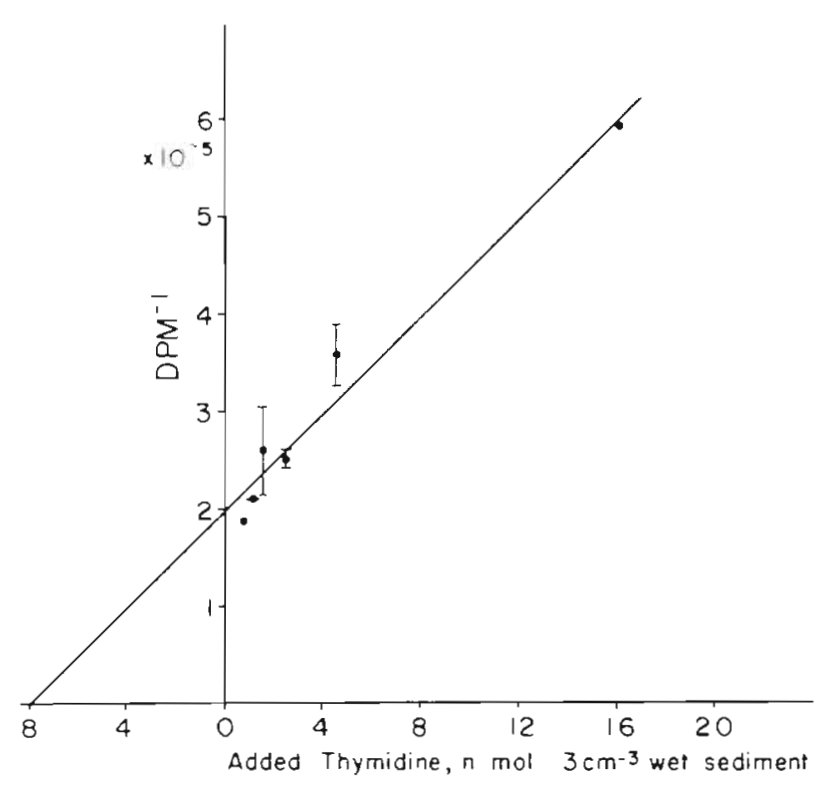

Fig. 1. Estimation of unlabeled thymidine pool based on the method of Moriarty and Pollard (1981) showing thymidine uptake, $\mathrm{DPM}^{-1}$, versus thymidine added, $\mathrm{n} \mathrm{mol} 3 \mathrm{~cm}^{-3}$ wet sediment. Bars: 1 standard deviation

Table 2. Conversion factors for estimating bacterial productivity in sediments

\begin{tabular}{|c|c|}
\hline $\begin{array}{l}\text { Thymidine } \\
0.38 \times 10^{18} \text { cells mole }{ }^{-1} \text { thymi- } \\
\text { dine (based on } 2.4 \times 10^{-15} \mathrm{~g} \\
\text { DNA cell-1 and } 25 \text { mole } \% \\
\text { thymidine) }\end{array}$ & Fuhrman and Azam (1982) \\
\hline $2.9 \times 10^{-14} \mathrm{~g} \mathrm{C} \mathrm{cell}^{-1}$ & Newell and Fallon (1982) \\
\hline $\begin{array}{l}1.89 \text { DPM incorporated/DPM } \\
\text { recovered from sand } \\
1.12 \text { DPM incorporated/DPM } \\
\text { recovered from mud }\end{array}$ & Present work \\
\hline $\begin{array}{l}16 \text { moles thymidine } \\
\text { incorporated/mole }{ }^{3} \mathrm{H} \\
\text { thymidine incorporated }\end{array}$ & Present work \\
\hline $\begin{array}{l}\text { Frequency of dividing cells } \\
\ln \mu=0.299 \text { FDC }-4.961 \\
\mu=\text { growth rate, } \mathrm{h}^{-1} \\
\text { Frequency of dividing cell, } \%\end{array}$ & Newell and Christian (1981) \\
\hline $100 \mathrm{mg} \mathrm{C} \mathrm{cm}{ }^{-3}$ cell volume & $\begin{array}{l}\text { Newell and Christian (1981) } \\
\text { (median value based on a } \\
\text { literature survey) }\end{array}$ \\
\hline
\end{tabular}

2B (THY) contrast the 2 estimates of bacterial productivity per unit volume. Results show FDC estimates ranged from 7.5 to 59 times higher than the THY values, except in one case (Station $5,20 \mathrm{~cm}$ ) where the FDC estimate was $116 \times 10^{-10} \mathrm{~g} \mathrm{C} \mathrm{cm}^{-3} \mathrm{~h}^{-1}$ and the THY estimate $125 \times 10^{-10} \mathrm{~g} \mathrm{C} \mathrm{cm}^{-3} \mathrm{~h}^{-1}$. No dividing cells were seen in this sample, so the upper limit for FDC productivity is reported. No consistent vertical trends in volumetric productivity emerged, but in the

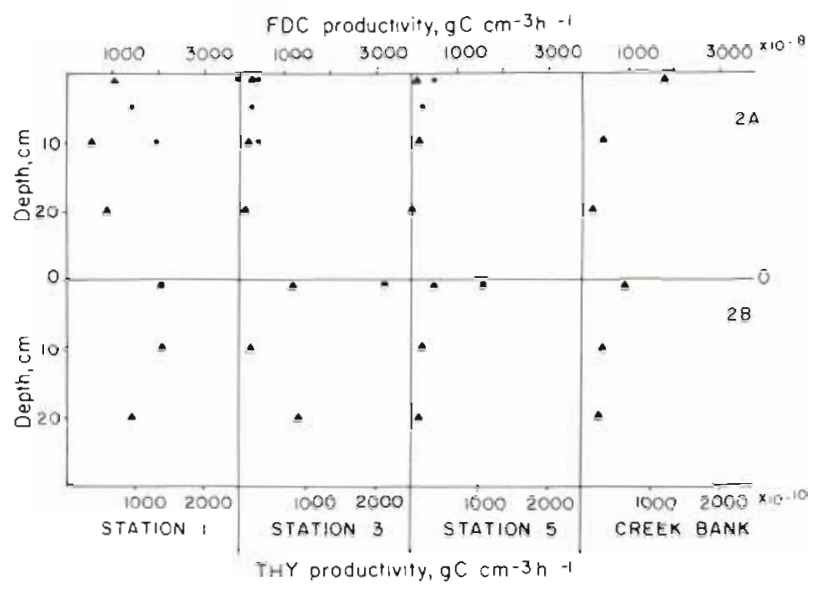

Fig. 2. (A) Carbon production by sedimentary bacteria based on FDC data. (B) Carbon production by sedimentary bacteria based on THY data. $\triangle$ October 1981; • June 1981; - February 1982

oceanic stations both FDC and THY estimates tended to decrease with increasing distance from shore for the 19 October data sets. Fig. $2 \mathrm{~A}$ and B also includes data for FDC productivity from the June 1981 cruise and thymidine uptake productivity in surface sediments from the February 1982 cruise. These data, in their respective ranges, are generally similar to that from the October cruise, indicating that October values derived from each of the two techniques were representative for the nearshore sediments.

Cell numbers and estimated turnover times are reported in Table 3 . Cell numbers were highest in the marsh creek sediments at $8.1 \pm 0.8 \times 10^{9}$ cells ml $^{-1}$ wet sediment. In the sandy ocean sediments, cell numbers at any one depth decreased with increasing distance from shore. In surface sediment, cell density decreased from $4.1 \pm 1.7 \times 10^{9} \mathrm{cells} \mathrm{ml}^{-1}$ wet sediment at $0.25 \mathrm{~km}$ offshore to $0.97 \pm 0.11 \times 10^{9}$ cells $\mathrm{ml}^{-1}$ wet sediment at $15 \mathrm{~km}$ offshore. At each station a trend of decreasing cell density with increasing depth was also observed (Table 3). Using these densities and dividing by the estimated cell production rates one arrives at estimates for population turnover, assuming a steady state population density. As shown in Table 3 . FDC estimates range from 16 to $60 \mathrm{~h}$, with the exception of Station 5, $20 \mathrm{~cm}$ depth. As would be expected from discussions above, THY estimates for turnover rates are much slower, ranging from 170 to $4400 \mathrm{~h}$.

Regressions relating cell number or FDC productivity to THY productivity were calculated and are shown in Fig. 3. The slope for FDC vs. THY is 0.98 for the data points from sand and 0.32 for the data points from mud. The correlation for cell numbers vs. THY also shows a greater slope in the sandy sediments (373) than in the mud (143). The r values (Fig. 3) indicate relatively strong correlations within each group. However, 
Table 3. Bacterial cell numbers and turnover times in coastal sediments, estimated from FDC and THY data

\begin{tabular}{|c|c|c|c|c|}
\hline \multirow[t]{2}{*}{ Location } & \multirow{2}{*}{$\begin{array}{c}\text { Depth } \\
(\mathrm{cm})\end{array}$} & \multirow{2}{*}{$\begin{array}{l}\text { Cells } \mathrm{ml}^{-1} \text { wet sediment } \\
\qquad\left(\times 10^{9}\right) \pm 1 \text { s.d. }\end{array}$} & \multicolumn{2}{|c|}{ Turnover time estimates (h) } \\
\hline & & & FDC & Thymidine uptake \\
\hline \multicolumn{5}{|l|}{ Marsh } \\
\hline & 0 & $8.1 \pm 0.8$ & 16 & 2800 \\
\hline & 10 & $4.3 \pm 0.5$ & 46 & 4400 \\
\hline & 20 & $3 \pm 0.4$ & 62 & 3800 \\
\hline \multicolumn{5}{|l|}{ Station 1} \\
\hline & 0 & $4.1 \pm 1.7$ & 18 & - \\
\hline & 10 & $3.2 \pm 0.7$ & 27 & 690 \\
\hline & 20 & $2.8 \pm 0.5$ & 14 & 920 \\
\hline \multicolumn{5}{|l|}{ Station 3} \\
\hline & 0 & $1.5 \pm 0.3$ & 27 & 540 \\
\hline & 10 & $0.78 \pm 0.02$ & 16 & 2100 \\
\hline & 20 & $0.64 \pm 0.0$ & 30 & 220 \\
\hline \multicolumn{5}{|l|}{ Station 5} \\
\hline & 0 & $0.97 \pm 0.11$ & 44 & 890 \\
\hline & 10 & $0.48 \pm 0.01$ & 15 & 940 \\
\hline & 20 & $0.07 \pm 0.008$ & $>140$ & 170 \\
\hline
\end{tabular}

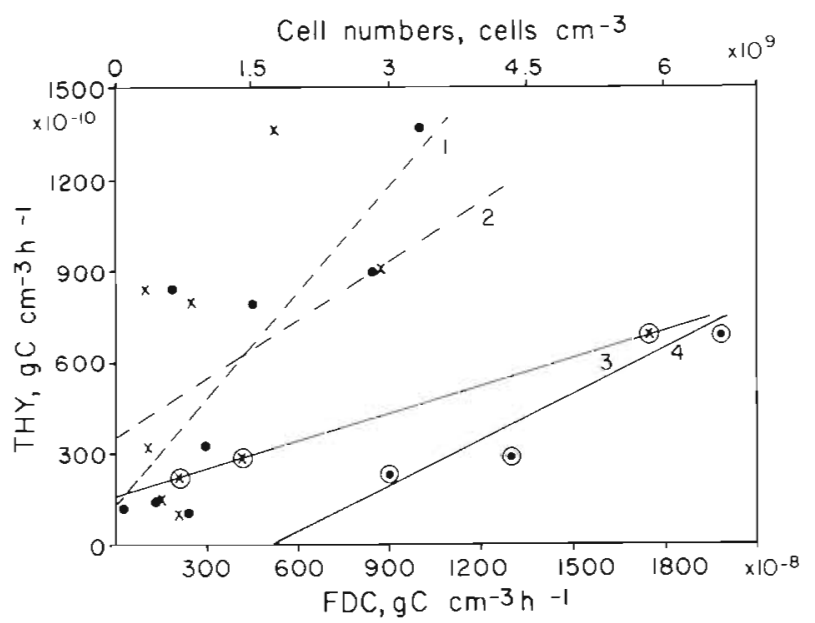

Fig. 3. Correlation analysis for cell numbers, FDC productivity estimates and THY productivity estimates. Data points: $\mathrm{X}=\mathrm{FDC}$ vs THY, sand; $\otimes=$ FDC vs THY, mud; $\bullet$ cell numbers vs THY, sand $O=$ cell numbers vs. THY, mud. Correlations: 1 : cell number vs. THY, sand, $\mathrm{r}^{2}=.84, \mathrm{n}=8 ; 2$ : FDC vs. THY, sand, $\mathrm{r}^{2}=.56, \mathrm{n}=7 ; 3$; FDC vs. THY, mud, $\mathrm{r}^{2}=$

$1, \mathrm{n}=3$; 4 ; cell number vs. THY, mud, $\mathrm{r}^{2}=.97, \mathrm{n}=3$

because there are so few data points, the relationships derived from the 2 sedimentary environments (sand and mud) cannot be separated statistically with a high level of confidence. From the values presented in Fig. 3 one can also derive cell specific uptake rates for thymidine in the 2 environments. Using the factor 0.91 $\times 10^{-13}$ moles thymidine ng $\mathrm{C}^{-1}$ (Table 2) and the mean value for ng C cell ${ }^{-1} \mathrm{~h}^{-1}$ from data in Fig. 3, 9.09 $\pm 2.06(\mathrm{SD}) \times 10^{-9}$ and $52.40 \pm 55.3(\mathrm{SD}) \times 10^{-9}$, for mud and sand, respectively, calculated cell specific uptake is $0.83 \times 10^{-21}$ for mud and $4.77 \times 10^{-21}$ mole thymidine cell ${ }^{-1} \mathrm{~h}^{-1}$ for sand. Although the value from sand is more than 5 -fold higher than the value from mud, the means are not significantly different at the $90 \%$ level of confidence because of the large variance and the few data points.

Areal rates of bacterial production for the 4 sites sampled in October 1981, based on FDC and THY techniques, are presented in Table 4. As one would expect from the volumetric rates (Fig. 2), estimates based on FDC are much greater than estimates based on THY. For the sandy nearshore sediments, the FDC:THY productivity ratios were $37: 1,20: 1$, and $30: 1$ for Stations 1, 3, and 5 respectively. In the marsh creek sediment the ratio was $114: 1$. Benthic respiration in the nearshore as measured by sediment oxygen uptake rates in the nearshore shows a decreasing trend with increasing distance from shore (Table 4). These respiration data provide us with maximal estimates for bacterial, productivity (i.e. if all sediment respiration is bacterial, a rough approximation, since bactivorous protozoa and meiofauna, and various macrofauna will contribute to sediment respiration). Assuming a growth efficiency of $50 \%$ (Payne, 1970), bacterial carbon production is equivalent to carbon respired. Comparing estimates from the FDC and THY techniques, one notes that in all enviroments THY productivity estimates are aligned with estimates from oxygen uptake data. In contrast FDC productivity values are far greater than the estimated maximum possible productivity derived from oxygen uptake.

\section{DISCUSSION}

In discussing the ${ }^{3} \mathrm{H}$ thymidine uptake results, one should be aware that a variety of factors contributes to 
Table 4. Production estimates $\left(\mathrm{gC} \mathrm{m}^{-2} \mathrm{~d}^{-1}\right)$

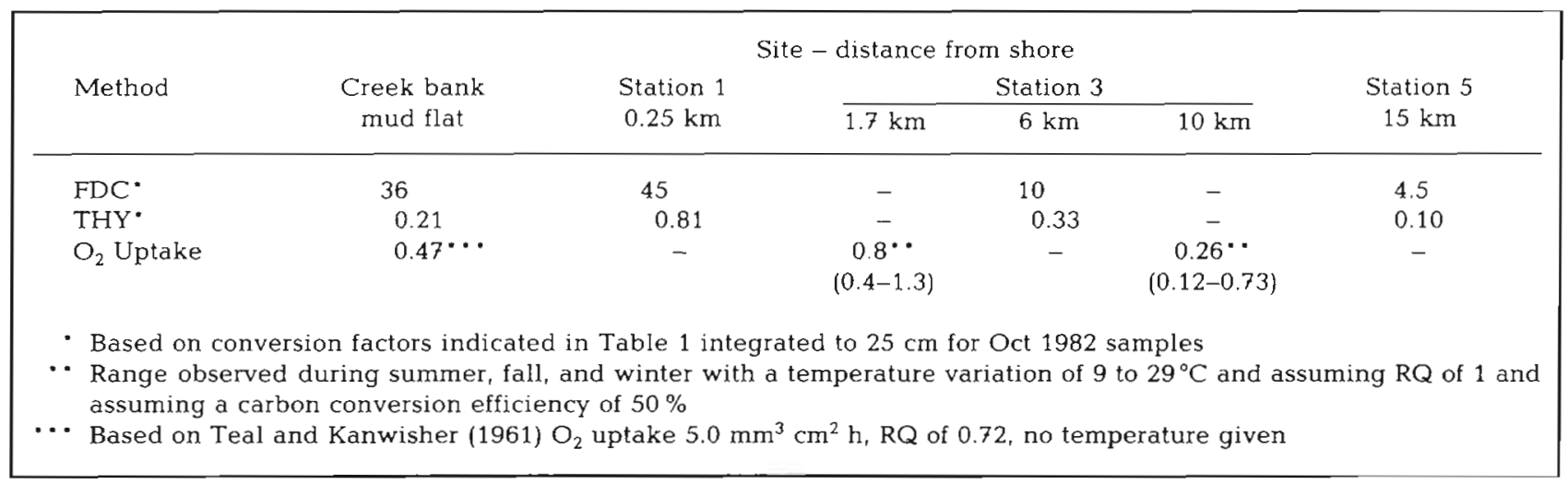

the uncertainty of the final estimate (Fuhrman and Azam, 1980). These factors, include (1) isotope dilution (Moriarty and Pollard, 1981; Fuhrman and Azam, 1982; Moriarty, in press); (2) factors for converting ${ }^{3} \mathrm{H}$ thymidine incorporation into biomass production (Fuhrman and Azam, 1980, 1982); (3) recovery of labeled product (Lorenz et al., 1981; Moriarty and Pollard, 1981); (4) the percentage of the bacterial population which incorporates ${ }^{3} \mathrm{H}$ thymidine (Ramsay, 1974; Fuhrman and Azam, 1982; Moriarty, in press). They should tend to cause the ${ }^{3} \mathrm{H}$ thymidine productivity estimates to fall below actual values (Fuhrman and Azam, 1980, 1982). As discussed below, attempts can be made to account for most of these factors, but much remains to be done in examining the influence of these factors on the productivity estimates.

Because cell numbers or radioactivity cannot be accurately counted in the presence of large quantities of particulates, in handling sediment samples, additional extraction or separation steps (not generally required in planktonic samples) must be used to separate the material of interest from interfering particles. The efficiency of these extraction steps must be evaluated in using either the FDC or THY techniques in sediments. This factor has been examined for cell counting by Meyer-Reil et al. (1978), who report mechanical homogenization to be the most effective treatment. Using this technique with a variety of sediments from coastal Georgia, separation efficiency was about $67 \%$ (range 60 to $72 \%$ ) (Newell and Fallon, 1982, and unpubl.). A number of prior observations show that DNA can strongly bind to soil and sediment particles in some cases (Greaves and Wilson, 1969; Lorenz et al., 1981). In the present study we noted lower recoveries of radioactivity in extraction from sandy sediments $(53 \%)$ vs. clay-silt sediments $(89 \%)$. This may indicate inefficient extraction from sand under basic conditions. Using perchloric acid extractions, Lorenz et al. (1981) have reported poor extraction in sand due to direct binding of the DNA to the particle surface. Another factor which may contribute to the observed differences in recovery is the generally higher humic acid content in the silt-clay sediments. Under acidic conditions the humics precipitate and may aid in precipitating the DNA, which would result in higher recovery efficiencies from the silt-clay sediments. In fact, Moriarty (in press) adds humic acids as an aid in DNA recovery from sediment extracts. We will require further testing in our systems to evaluate the effects of humic acids on label recovery.

Isotope dilution in sediments is also of concern. We must attempt to discover the ${ }^{3} \mathrm{H}$ thymidine/total thymidine incorporated ratio. Extracellular pools may dilute the added label, especially in sediments where organic pools may be high (Moriarty and Pollard, 1981). Also, bacterial cells synthesize thymidine, which will further dilute the added ${ }^{3} \mathrm{H}$ thymidine when incorporated into endogenous precursor pools for DNA synthesis (Rosenbaum-Oliver and Zamenhof, 1972). Moriarty and Pollard (1981) have suggested a way in which to estimate isotope dilution in the ${ }^{3} \mathrm{H}$ thymidine method. As a means of convenience, they express these pool values in terms of $n$ mole $\mathrm{g}^{-1}$ wet sediment. We also use this convention, but one should recall that this value refers to pools both external to and within bacterial cells in the sediments. Although some of their observations are open to alternative interpretations, we chose to apply the Moriarty and Pollard (1981) approach in the current study in order to evaluate its utility in our system. The main reservation concerning Moriarty and Pollard's (1981) results is the interpretation of a non-linear response curve as indicating the presence of two thymidine pools. Such a response could also result from physiological determinants in the bacterial populations, such as enzyme systems with differing substrate affinities. We observed no such responses, and the thymidine pool was estimated to be $1.5 \mathrm{n} \mathrm{mol} \mathrm{g}^{-1}$ wet sediment $\left(=2.7 \mathrm{n} \mathrm{mol} \mathrm{ml}^{-1}\right.$ wet sediment) in the surface sediment at Station 1. This value is almost 10 -fold lower than the maximum pools 
$\left(\approx 10 \mathrm{n} \mathrm{mol} \mathrm{g}^{-1}\right.$ wet sediment) reported for seagrass bed sediments but is similar to the values generally found in seagrass bed sediments where only one thymidine pool was evident $\left(0.58 \mathrm{n} \mathrm{mol} \mathrm{g}^{-1}\right.$ wet sediment) (Moriarty and Pollard, 1981). Sediments from Station 1 are exposed to organic matter input from water draining the marsh and thus might be expected to be enriched in metabolizable compounds relative to sediments offshore. If this is the case, assignment of the correction factor derived from nearshore sediments (Table 2) to sediments with lower thymidine pools will overestimate the amount of isotope dilution. Thus, THY productivity estimates for Stations 3 and 5 should be considered maximum estimates, with the degree of possible error determined by the difference in values of the actual vs, assigned sedimentary thymidine pools.

In comparing $\mathrm{THY}$ and FDC productivity data we noted little evidence for decreasing production with increasing sediment depth, although cell numbers did tend to decrease with depth. The only consistent trend was observed in the marsh sediments where production estimates at the 10 and $20 \mathrm{~cm}$ depths were onehalf and one-quarter the surface values for THY and FDC productivity estimates, respectively. Vertical gradients in bacterial activity are often observed in sediments (Wieser and Zech, 1976; Vosjan and OlanczukNeyman, 1977; Tobin and Anthony, 1978; Aller and Yingst, 1980). However, such gradients are not always found (Inniss and Young, 1977; Christensen and Devol, 1980) and, since sediments at the nearshore stations reported here are subject to wave turbulence and high levels of bioturbation (Howard and Reineck, 1972), mixing will tend to bring metabolizable organic material to deeper sediments. The relatively small decrease in cell densities with increasing depth observed at Stations 1 and 3 support this contention.

Regression analyses comparing cell number, FDC productivity, and THY productivity appear to indicate a positive correlation between cell density and thymidine productivity in sediments. This correlation was not studied by Moriarty and Pollard (1981), but has been seen by others in a variety of planktonic systems (Fuhrman and Azam, 1980; Fuhrman et al., 1980; Newell and Fallon, 1982; Hanson et al., unpubl.). It indicates that a relatively constant percentage of any population is active in thymidine incorporation over a wide range of cell densities and that thymidine uptake per cell is similar in all samples from each environment. The relationship of FDC vs. THY and cell numbers vs. THY appears to differ in mud and sand, as indicated by the differing slopes demonstrated for the two environments in the correlation analysis. In the nearshore ocean, the correlations of FDC vs. THY and cell number vs. THY are higher in the water column $\left(\mathrm{r}^{2}\right.$
$=0.94$ and $\mathrm{r}^{2}=0.91$, respectively) (Newell and Fallon, 1982) than in sediments $\left(r^{2}=0.56\right.$ and $r^{2}=0.84$, respectively). This may simply reflect greater inhomogeneity in the sediments (Anderson and Meadows, 1978; Jones et al., 1979) than in the water column, or it may indicate that in sediments there are additional factors, unimportant in the water column, that influence these estimators.

From the data on cell number and THY we obtained cell specific uptake rates of $4.77 \times 10^{-21}$ moles thymidine cell ${ }^{-1} \mathrm{~h}^{-1}$ for sand (nearshore) and $0.83 \times$ $10^{-21}$ for mud (marsh). These rates are substantially slower than those reported by Moriarty and Pollard (1981) for seagrass bed sediments. They are at the low end or below the range of values (uncorrected for possible isotope dilution) reported for the water column at Stations 1,3 , and 5 (3 to $10 \times 10^{-21}$ moles cell ${ }^{-1}$ $\mathrm{h}^{-1}$ ) by Newell and Fallon (1982) and at the low end of the range from other workers using the thymidine uptake technique (Fuhrman and Azam, 1980; Fuhrman et al., 1980; Ducklow, 1982; Hanson et al., unpubl.).

The availability of sediment oxygen uptake data allows us an independent estimator of maximum bacterial productivity against which we can test estimates derived from FDC and THY techniques. Based on these comparisons, it appears that the THY technique yields a much more reasonable estimate for production than does FDC. In all cases FDC estimates appear much too high. It should be noted that based on the data of Hopkinson and Wetzel (1982), dinitrogen resulting from denitrification, may be lost from the sediments. This would cause the oxygen uptake measurements to underestimate true respiratory rates, since dinitrogen is unlikely to be reoxidized as it moves through the aerobic surface sediments. However, even if we assume that all denitrification is missed by the oxygen uptake method, data from Hopkinson and Wetzel (1982) indicate that this source of energy is equivalent to only $5 \%$ of that available from aerobic respiration. An underestimation of such magnitude cannot account for the observed differences between the FDC and oxygen uptake productivity estimates. As noted by Newell and Fallon (1982) the FDC estimates are so high that they cannot be accounted for even if one assumes that all carbon produced in the overlying water column and in the landward saltmarshes is available for bacterial production in the nearshore sediments. In addition, the estimated turnover times based on thymidine also are in agreement with most previous reports on sedimentary bacteria, indicating a relatively low cellular activity in sedimentary populations (Meyer-Reil et al., 1978; Pamatmat et al., 1981).

Newell and Fallon (1982) reported very high FDC productivity estimates for coastal Georgia sediments 
and FDC productivity estimates in the current data are also unreasonably high. These results suggest that calibrations for FDC vs. growth rate derived from water column populations cannot be used for sedimentary populations. Two possible reasons for this are the following. First, the relationship between growth rate and the time period between wall constriction and cell separation is still poorly understood (Grover et al., 1977). If, as indicated by the THY technique and respiration rates, the average generation time of bacteria in the sediments is quite long, perhaps the cell-separation time vs. growth rate relationship is altered at these slow rates, resulting in a different FDC vs. growth rate relationship from that in the water column. Second, the nature of cell growth in sediments is poorly understood. Prior to homogenization, most cells are associated with surfaces in the sediments and surface associated cells may not separate readily from one another after division, being held together by the glycocalyx coating (Costerton et al., 1981) with which they adhere to sediment particles. If such cells are separated from the sediment particle by the homogenization step, but are not separated from one another, they may be mistaken for dividing cells, thus increasing the dividing cell frequency. In either case, it appears that determining FDC vs. growth rate relationships in sediments will be difficult. Without these data, however, there appears to be little chance of accurately determining bacterial productivity in sediments using the FDC approach. In contrast, the results reported here show that the thymidine-uptake approach may prove useful for estimating bacterial productivity in sediments. Further study and refinement of the thymidine uptake approach will be necessary before a more definitive judgment can be made.

Acknowledgements. We thank J. Harris and G. Walker for help aboard the R/V 'Spartina', H. W. Ducklow for providing critical comments on this communication, and Lorene Gassert for illustrations. Financial support was granted by the Sapelo Island Research Foundation. This is contribution 473 of the University of Georgia Marine Institute.

\section{LITERATURE CITED}

Aller, R. C., Yingst, J. Y. (1980). Relationships between microbial distributions and the anaerobic decomposition of organic matter in surface sediments of Long Island Sound, U.S.A. Mar. Biol. 56: 29-42

Anderson, J. G., Meadows, P. S. (1978). Microenvironments in sediments. Proc. R. Soc. Edinb. 76B: 1-16

Chocair, J. A., Albright, L. J. (1981). Heterotrophic activities of bacterioplankton and bacteriobenthos. Can. J. Microbiol. 27: 259-266

Christensen, J. P., Devol, A. H. (1980). Adenosine triphosphate and adenylate energy charge in marine sediments. Mar Biol. 56: 175-182

Christian, R. R., Bancroft, K., Wiebe, W. J. (1978). Resistance of the microbial community within salt marsh soils to selected perturbations. Ecology 59: 1200-1210

Christian, R. R., Wiebe, W. J. (1978). Anaerobic microbial community metabolism in Spartina alterniflora soils. Limnol. Oceanogr. 23: 328-336

Costerton, J. W., Irvin, R. T., Cheng, K.-T. (1981). The bacterial glycocalyx in nature and disease. A. Rev. Microbiol 35: $299-324$

Delattre, J. M., Delesmont, R., Clabaux, M., Oger, C., Leclerc, H. (1979). Bacterial biomass, production, and heterotrophic activity of the coastal seawater at Gravelines (France). Oceanol. Acta 2: 317-324

Ducklow, H. W. (1982). Bacterial biomass and production during spring tidal destratification in the York River, Virginia, estuary, Limnol. Oceanogr. 27: 651-659

Fenchel, T., Blackburn, T. H. (1979). Bacteria and mineral cycling. Academic Press

Fuhrman, J. A., Ammerman, J. W., Azam, F. (1980). Bacterioplankton in the coastal euphotic zone: distribution activity and possible relationships with phytoplankton. Mar. Biol. 60: 201-207

Fuhrman, J. A., Azam, F. (1980). Bacterioplankton secondary production estimates for coastal waters of British Columbia, Antarctica, and California. Appl. environ. Microbiol. 39: $1085-1095$

Fuhrman, J. A., Azam, F. (1982). Thymidine incorporation as a measure of heterotrophic bacterioplankton production in marine surface waters; evaluation and field results. Mar. Biol. 66: 109-120

Gerlach, D. A. (1978). Food chain relationships in subtidal silty sand marine sediments and the role of meiofauna in stimulating bacterial productivity. Oecologia (Berl.) 33: $55-69$

Greaves, M. P., Wilson, M. J. (1969). The adsorption of nucleic acid to montmorillonite. Soil Biol. Biochem. 1: 317-323

Grover, N. B., Woldringh, C. L., Zaritsky, A., Rosenberger, R. F. (1977). Elongation of rod shaped bacteria. J. theor. Biol. 67: $181-193$

Hagström, A. U., Hörstedt, P., Normark, S. (1979). Frequency of dividing cells, a new approach to the determination of bacterial growth rates in aquatic environments. Appl. environ. Microbiol. 37: 805-812

Hargrave, B. T. (1969). Similarity of oxygen uptake by benthic communities. Limnol. Oceanogr. 14: 801-805

Hartwig, E. O. (1978). Factors affecting respiration and photosynthesis by the benthic community of a siliceous sediment. Mar. Biol. 46: 283-293

Hobbie, J. E., Daley, R. J., Jasper, S. (1977). Use of nuclepore filters for counting bacteria by fluorescence microscopy. Appl. environ. Microbiol. 3: 1225-1228

Hopkinson, C. S., Wetzel, R. L. (1982). In situ measurements of nutrient and oxygen fluxes in a coastal marine benthic community. Mar. Ecol. Progr. Ser. 10: 29-35

Howard, J. D., Frey, R. W., Reineck, H.-E. (1972). Georgia coastal region, Sapelo Island, U.S.A.: Sedimentology and biology, I. Introduction. Senckenbergiana Marit. 4: 3-14

Howard, J. D., Reineck, H.-E. (1972). Georgia coastal region, Sapelo Island, U.S.A. IV. Physical and biogenic sedimentary structures of the nearshore shelf. Senckenbergiana Marit. 4: 61-123

Inniss, W. E., Young, M. (1977). Metabolic activity in cores of lake-bottom sediments. Wat. Res. 11: 75-77

Jones, J. G., Orlandi, M. J. L. G., Simon, B. M. (1979). A microbiological study of sediments from the Cumbrian lakes. J. gen. Microbiol. 115: 37-48

Jørgensen, B. B. (1978). A comparison of methods for the quantification of bacterial sulfate reduction in coastal 
marine sediments. I. Measurement with radiotracer techniques. Geomicrobiol. J. 1: 11-28

Karl, D. M., Winn, C. D., Wong, D. C. L. (1981a). RNA synthesis as a measure of microbial growth in aquatic environments. I. Evaluation, verification and optimazation of methods. Mar. Biol. 64: 1-12

Karl, D. M., Winn, C. D., Wong, D. C. L. (1981b). RNA synthesis as a measure of microbial growth in aquatic environments. II. Field applications. Mar. Biol. 64: 13-21

Lorenz, M. G., Aardema, B. W., Krumbein, W. E. (1981). Interaction of marine sediment and DNA and DNA availability to nucleases. Mar. Biol. 64: 225-230

Meyer-Reil, L.-A., Dawson, R., Liebezeit, G., Tiedge, H. (1978). Fluctuations and interactions of bacterial activity in sandy beach sediments and overlying waters. Mar. Biol. 48: $161-171$

Meyer-Reil, L.-A., Faubel, A. (1980). Uptake of organic matter by meiofauna organisms and interrelationships with bacteria. Mar. Ecol. Prog. Ser. 3: 251-256

Moriarty, D. J. W. (1977). Improved method using muramic acid to estimate biomass of bacteria in sediments. Oecologia (Berl.) 26: 317-323

Moriarty, D. J. W. (in press). Measurement of bacterial growth rates in marine systems using nucleic acid precursors. In: Hobbie, J. E., Williams, P. J. LeB (eds.) Heterotrophic activity in the sea. Plenum Press, New York

Moriarty, D. J. W., Pollard, P. C. (1981). DNA synthesis as a measure of bacterial productivity in seagrass sediments. Mar. Ecol. Prog. Ser. 5: 151-156

Newell, S. Y., Christian, R. R. (1981). Frequency of dividing cells as an estimator of bacterial productivity. Appl. environ. Microbiol. 42: 23-31

Newell, S. Y., Fallon, R. D. (1982). Bacterial productivity in the water column and sediments of the Georgia (USA) coastal zone: estimates via direct counting and parallel measurement of thymidine incorporation. Microb. Ecol. 8: $33-46$

Nixon, S. W., Kelly, J., Furnas, B., Oviatt, C., Hale, S. (1980). Phosphorus regeneration and the metabolism of coastal marine bottom communities. In: Tenore, K., Coull, B. (eds.) Marine benthic dynamics. University of South Carolina Press, Columbia, p. 219-242

Novitsky, J. A., Kepkay, P. E. (1981). Patterns of microbial heterotrophy through changing environments in a marine sediment. Mar. Ecol. Prog. Ser. 4: 1-7

Pamatmat, M. M., Graf, G., Bengtsson, W., Novak, C. S. (1981). Heat production, ATP concentration and electron transport activity of marine sediments. Mar Ecol. Prog. Ser. 4: $135-143$
Payne, W. J. (1970). Energy yields and growth of heterotrophs A. Rev. Microbiol. 24: 17-47

Pinet, P. R., Frey, R. W. (1977). Organic carbon in surface sands seaward of Altamaha and Doboy Sounds, Georgia. Geol. Soc. Am. Bull. 88: 1731-1739

Ramsay, A. J. (1974). The use of autoradiography to determine the proportion of bacteria metabolizing in an aquatic habitat. J. gen. Microbiol. 80: 363-373

Robertson, J. R., Newell, S. Y. (1982). Experimental studies of particle ingestion by the sand fiddler crab Uca pugilator (Bosc.). J. exp. mar. Biol. Ecol. 59: 1-21

Rosenbaum-Oliver, D., Zamenhof, S. (1972). Degree of exogenous thymidine in the overall deoxyribonucleic acid synthesis in Escherichia coli. J. Bacteriol. 110: 585-591

Rublee, P. A., Cammen, L. M., Hobbie, J. E. (1978). Bacteria in a North Carolina salt marsh: standing crop and importance in the decomposition of Spartina alterniflora. University of North Carolina Sea Grant Publ. UNC-SG-78-11: $1-80$

Sieburth, J. M., Johnson, K. M., Burney, C. M., Lavoie, D. M. (1977). Estimation of in situ rates of heterotrophy using diurnal changes in dissolved organic matter and growth rates of picoplankton in diffusion cultures. Helgoländer wiss. Meeresunters. 30: 565-574

Smith, K. L. (1974). Oxygen demands of San Diego Trough sediments, an in situ study. Limnol. Oceanogr. 19: 939-944

Sørensen, J., Jørgensen, B. B., Revsbech, N. P. (1979). A comparison of oxygen, nitrate, and sulfate respiration in coastal marine sediments. Microb. Ecol. 5: 105-115

Sorokin, Y. I. (1981). Microheterotrophic organisms in marine ecosystems. In: Longhurst, A. R. (ed.) Analysis of marine ecosystems. Academic Press, New York, p. 293-342

Teal, J. M., Kanwisher, J. (1961). Gas exchange in a Georgia salt marsh. Limnol. Oceanogr. 6: 388-399

Tobin, R. S., Anthony, D. H. J. (1978). Tritiated thymidine incorporation as a measure of microbial activity in lake sediments. Limnol. Oceanogr. 23: 161-165

Van Es, F. B. (1982). Community metabolism of interstitial flats in the Ems-Dollard estuaries. Mar. Biol. 66: 95-108

Vosjan, J. H., Olanczuk-Neyman, K. M. (1977), Vertical distribution of mineralization processes in a tidal sediment. Neth. J. Sea Res. 11: 14-23

Wieser, W., Zeck, M. (1976). Dehydrogenases as tools in the study of marine sediments. Mar. Biol. 36: 113-122

Yetka, J. E., Wiebe, W. J. (1974). Ecological application of antibiotics as respiratory inhibitors of bacterial populations. Appl. Microbiol. 28: 1033-1039 